\title{
A primitive heron (Aves: Ardeidae) from the Miocene of Central Asia
}

\author{
Andrzej Elzanowski $\cdot$ Nikita V. Zelenkov
}

Received: 14 October 2014/Revised: 1 January 2015/Accepted: 19 January 2015/Published online: 11 February 2015

(C) The Author(s) 2015. This article is published with open access at Springerlink.com

\begin{abstract}
A robust quadrate from the Middle Miocene of Mongolia represents a new genus of Ardeidae that combines the similarities to Nycticorax and Tigrisoma, both of which have been recovered in basal positions in recent phylogenies of the Ardeidae, and to cf. Pikaihao from the Middle Miocene of Africa. The confluence of mandibular facets on the medial condyle and pterygoid condyle in the new genus, Nycticorax, and cf. Pikaihao is likely to be symplesiomorphic, as it is shared with nearly all other waterbirds (except for the Ciconiidae), including the immediate outgroup (Threskiornithidae). However, the medial supraorbital crest is a likely synapomorphy of the new genus and cf. Pikaihao. The similarities to Trigrisoma support its basal position, as recovered from molecular sequences and proposed by a pre-cladistic morphological analysis. Since both the night herons and Tigrisoma have heads that are proportionally much larger than those of the large day herons, it appears that the Ardeidae started their evolution with relatively heavy heads, which may have contributed to the origins of the family-specific head retraction in flight.
\end{abstract}

Communicated by F. Bairlein.

Electronic supplementary material The online version of this article (doi:10.1007/s10336-015-1164-y) contains supplementary material, which is available to authorized users.

A. Elzanowski $(\bowtie)$

Museum and Institute of Zoology, Polish Academy of Sciences, 64 Wilcza Street, 00-679 Warsaw, Poland

e-mail: elzanowski@miiz.waw.pl

N. V. Zelenkov

Borissiak Paleontological Institute, Russian Academy of Sciences, Profsoyuznaya ul. 123, Moscow 117997, Russia

e-mail: nzelen@paleo.ru
Keywords Fossil birds · Quadrate skull ·

Neck curvature $\cdot$ Miocene

\section{Zusammenfassung}

Ein primitiver Reiher (Aves: Ardeidae) aus dem Miozän Zentralasiens

Aufgrund eines robusten Quadratums aus dem MittelMiozän der Mongolei wird eine neue Art und Gattung der Ardeidae erstellt. Das Quadratum verbindet die Merkmale von Tigerreihern (Tigrisoma) und Nachtreihern (besonders Nycticorax), die wiederholt in basalen Stellungen in Stammbäumen der Ardeidae resultierten, als auch von cf. Pikaihao aus dem Mittel-Miozän Afrikas. Das Verschmelzen der Mandibularfazetten auf dem condylus mandibularis medialis und condylus pterygoideus, wie auch bei Nycticorax und cf. Pikaihao, weist auf einen primitiven Vertreter der Ardeidae hin weil es dem ganzen Stamm der Wasservögel (bis auf Ciconiidae) eigen ist und auch bei der unmittelbaren Außengruppe (Threskiornithidae) vorkommt. Jedoch erscheint die crista suprorbitalis medialis als eine Synapomorphie der Nyctisoma und cf. Pikaihao. Die Gemeisamkeiten mit Tigrisoma dagegen erweisen sich eher als symplesiomorph und bestätigen die basale Stellung von Tigerreihern, die von einer prä-kladistischen Analyse und einer Molekularphylogenie nicht aber von den rezenten kladistischen, aufgrund der morphologischen Merkmalen berechneten Stammbäumen festgestellt wurde. Sowohl bei den Tigerreihern als auch bei den Nachtreihern sind die Köpfe relativ größer als bei den großen Tagreihern, was darauf hindeutet, dass der Kopf auch bei den ancestralen Ardeidae relativ schwer war und damit zur Entstehung der S-förmigen Halsbeugung im Fluge beitragen konnte. 


\section{Introduction}

The family Ardeidae (herons, night herons and bitterns) comprises 62 extant species in 17 genera (Kushlan and Hancock 2005). The ardeid lineage must have split from its sister group, the Threskiornithidae (Hackett et al. 2008) by the Middle Eocene, when the oldest ibis has been identified (Mayr 2009). However, no stem-group ardeid has ever been identified and no Eocene predecessors of herons have yet been found, except for the inherently questionable tracks (Mustoe 1993). The oldest unquestionable ardeid fossils come from the early Oligocene (Mayr 2009), including remnants of two unnamed species from the Jebel Qatrani formation of Egypt, one of them being a tarsometatarsus that is indistinguishable from that of extant night herons Nycticorax (Rasmussen et al. 1987). Proardea amissa has been recorded form the late Oligocene of Quercy (Mayr 2009). In the early Miocene, Proardeola walkeri was widespread across Europe and Asia (Zelenkov 2011 and references therein), and two approximately coeval species, an unusual ardeid Matuku otagoenese and a putative botaurine Pikaihao bartlei, have been described from New Zealand (Scofield et al. 2010; Worthy et al. 2013). A coracoid of a large ardeid, possibly a Cochlearius relative, has been described as Zeltornis ginsburgi from the lower Miocene of northern Africa (Balouet 1981). In the middle Miocene, the extant genus Ardea appears to be of North America (Becker 1986) and Asia, where two other unnamed species, one of them assigned to the Botaurinae, have also been found (Zelenkov 2011). An ardeid identified as cf. Pikaihao was reported from the middle Miocene of Africa (Mayr 2014). A morphologically unique tarsometatarsus of a large ardeid (the size of Ardea goliath) has been described as Ardeagrandis arborea from the late middle to early late Miocene of Moldova (Kurochkin and Ganya 1972). The late Miocene record of Ardeidae consists primarily of the extant genera (Ardea, Ardeola, Botaurus, Egretta, Nyctanassa, Nycticorax).

The quadrate is one of the most frequently preserved, single cranial bones in the avian fossil record, and yet up until recently, it has been given little attention by avian paleontologists, certainly due to the lack of any detailed comparative study of this bone in extant birds. The situation has greatly improved only recently, allowing Scofield et al. (2010) to provide a detailed description of the unusual ardeid quadrate (with an enormous tympanic crest) of Matuku otagoense, and Mayr (2014) illustrated the quadrate of cf. Pikaihao. For extant species, Payne and Risley (1976) compared some cranial details in most ardeid species, but paid little attention to the quadrate, except for finding it strikingly different in Cochlearius (which is correct) and noting a variation in the position of "a small pneumatic foramen," "particularly among the night herons." The latter observation is mistaken; in fact, the position of the caudomedial foramen, shared with the related Threskiornithidae, is remarkably stable among the Ardeidae, although the foramen varies in shape. Measurements from numerous specimens of Nycticorax nycticorax and Nyctanassa violacea have demonstrated moderate sexual dimorphism in the size of quadrates (Adams 1955), and permit calculating their intraspecies and intrasex variability as $109-115 \%$ of the smallest specimen, which should be taken into account by avian paleontologists who often establish new species based on size differences. In addition, Bas (1954) illustrated the quadrate in Ardea cinerea to show the origin area of the protractor pterygoidei et quadrati.

Here, we describe a quadrate belonging to a new species and genus of a primitive heron from the Middle Miocene Sharga locality in Mongolia, which is one of the richest localities of Neogene birds of Asia (Zelenkov and Kurochkin 2011). This locality yielded numerous avian fossils (see Zelenkov 2013 for review), including a new species, Ardea sytchevskayae, and two unnamed species based on very fragmentary material: one, larger, referred to Botaurinae and another, smaller, that could not be referred to any taxon (Zelenkov 2011).

\section{Materials and methods}

The quadrate is lacking most of the orbital process and approximately the distal half of the pterygoid condyle (the entire pterygoid facet and the distal part of the secondary mandibular facet are cut off). Otherwise, the bone is well preserved. The anatomical terminology (formal Latin in Fig. 1 and anglicized in the text) follows Elzanowski et al. (2000) with a few additions.

For comparisons we surveyed 24 extant species in 14 genera of Ardeidae: Agamia agami, Ardea alba, A. cinerea, A. goliath, A. herodias, A. melanocephala, A. purpurea, Ardeola ralloides, Botaurus stellaris, Butorides striata, Bubulcus ibis, Cochlearius cochlearius, Egretta caerulea, E. garzetta, E. thula, Gorsachius melanolophus, Ixobrychus eurhythmus, I. minutus, Nyctanassa violacea, Nycticorax caledonicus, N. nycticorax, Syrigma sibilatrix, Tigrisoma lineatum and T. mexicanum. In addition, we included into comparisons the quadrates of two fossil species: Matuku otagoense, as described by Scofield et al. (2010), and cf. Pikaihao, using the original photographs for Mayr (2014; Fig. 2a-e).

We used Threskiornithidae as an immediate outgroup, following Hackett et al. (2008). Although the quadrates of the threskiornithids and ardeids are dissimilar in most details, they share the caudomedial foramen, which is therefore a likely synapomorphy of these two families, whereas 
Fig. 1 Left quadrates of Ardeidae. a Nycticorax nycticorax, b Nyctisoma robusta holotype PIN 4869/52 from the middle Miocene of Sharga locality (Western Mongolia), c Tigrisoma mexicanum, d Nyctanassa violacea, e Botaurus stellaris, f Gorsachius melanolophus in 1, rostral and 2, caudal views. Scale bars $5 \mathrm{~mm}$. bo fossa basiorbitalis. $c$ condylus mandibularis caudalis. $\mathrm{cl}$ crista lateralis. $\mathrm{cm}$ crista medialis, $\mathrm{co}$ crista orbitopterygoidea, $c s$ crista supraorbitalis medialis, $c t$ crista tympanica, $d c$ depressio caudomedialis, $d r$ depressio rostromedialis, $d s$ depressio supracondylaris, $f$ foramen pneumaticum adventitium (ectopic pneumatic foramen), $f c$ foramen pneumaticum caudomediale, $i$ incisura intercondylaris, $l$ condylus mandibularis lateralis, $m$ condylus mandibularis medialis, $m p$ secondary mandibular facet on the pterygoid condyle, $m t$ trochlea of the medial condyle, $o$ capitulum oticum, or processus orbitalis, $p$ pterygoid facet on the pterygoid condyle, po pterygoid facet on the orbital process, $q$ cotyla quadratojugalis, $r$ ligament attachment rugosity,

$s$ capitulum squamosum, $t$ tuberculum subcapitulare, $v$ vallecula intercapitularis
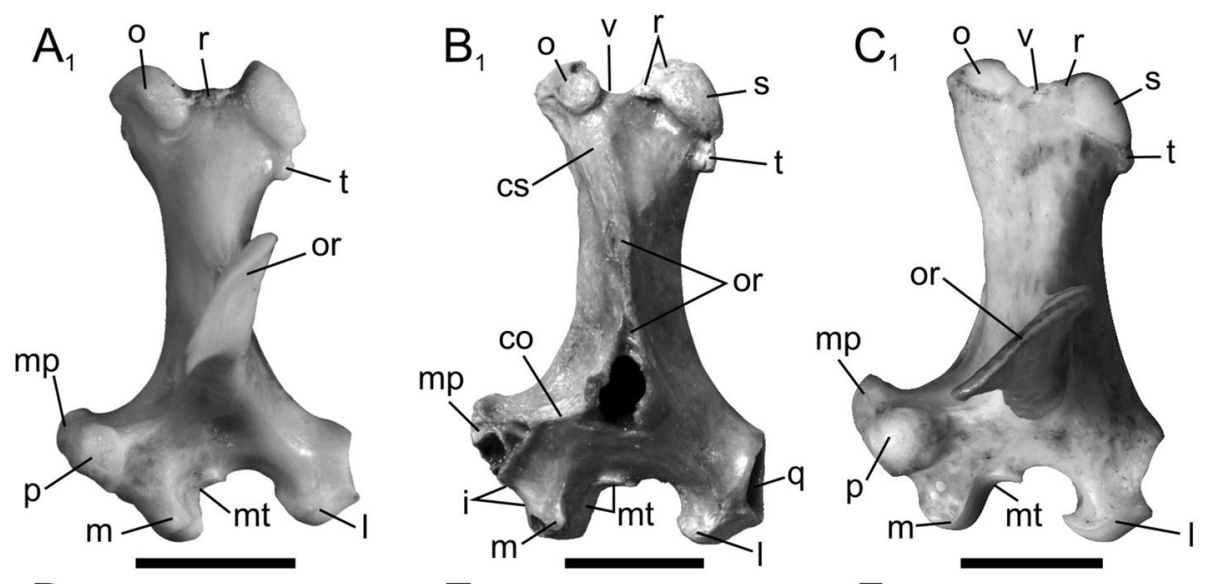

$D_{1}$

$\mathrm{E}_{1}$
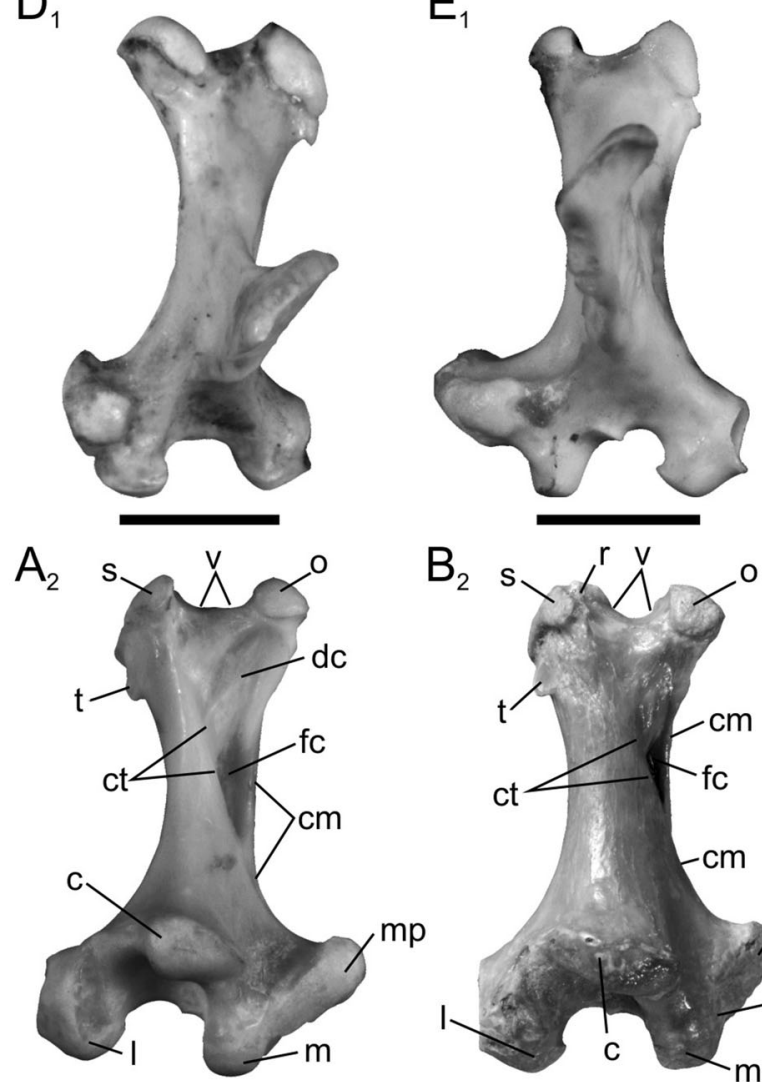

$\mathrm{B}_{2}$
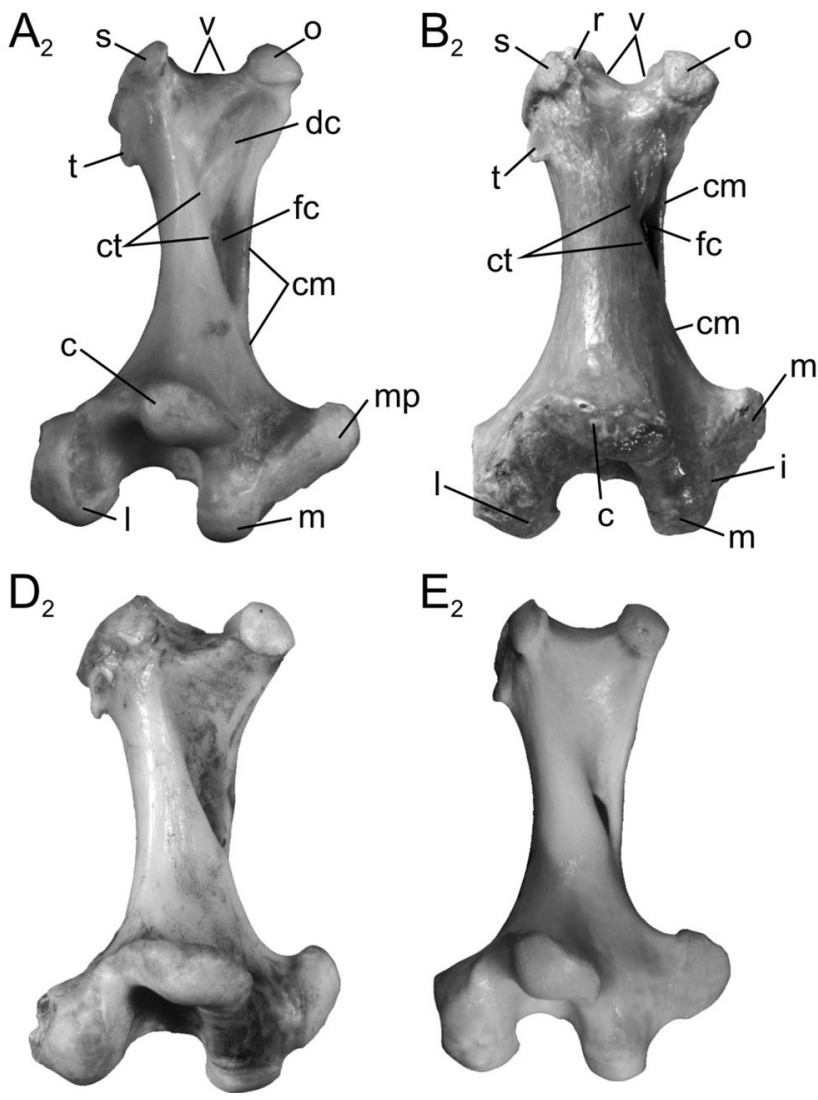
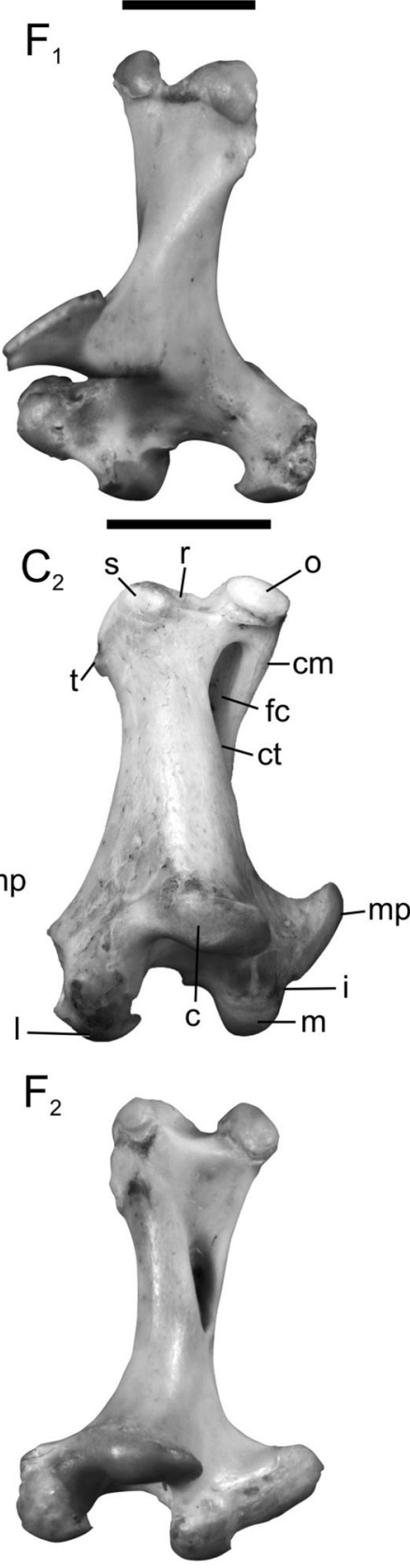
Fig. 2 Left quadrates of Ardeidae. a Nycticorax nycticorax, b Nyctisoma robusta holotype PIN 4869/52 from the middle Miocene of Sharga locality (Western Mongolia), c Tigrisoma mexicanum,

d Nyctanassa violacea, e Botaurus stellaris, f Gorsachius melanolophus in 1 , medial and 2, lateral views.

Scale bars $5 \mathrm{~mm}$. Abbreviations as in Fig. 1
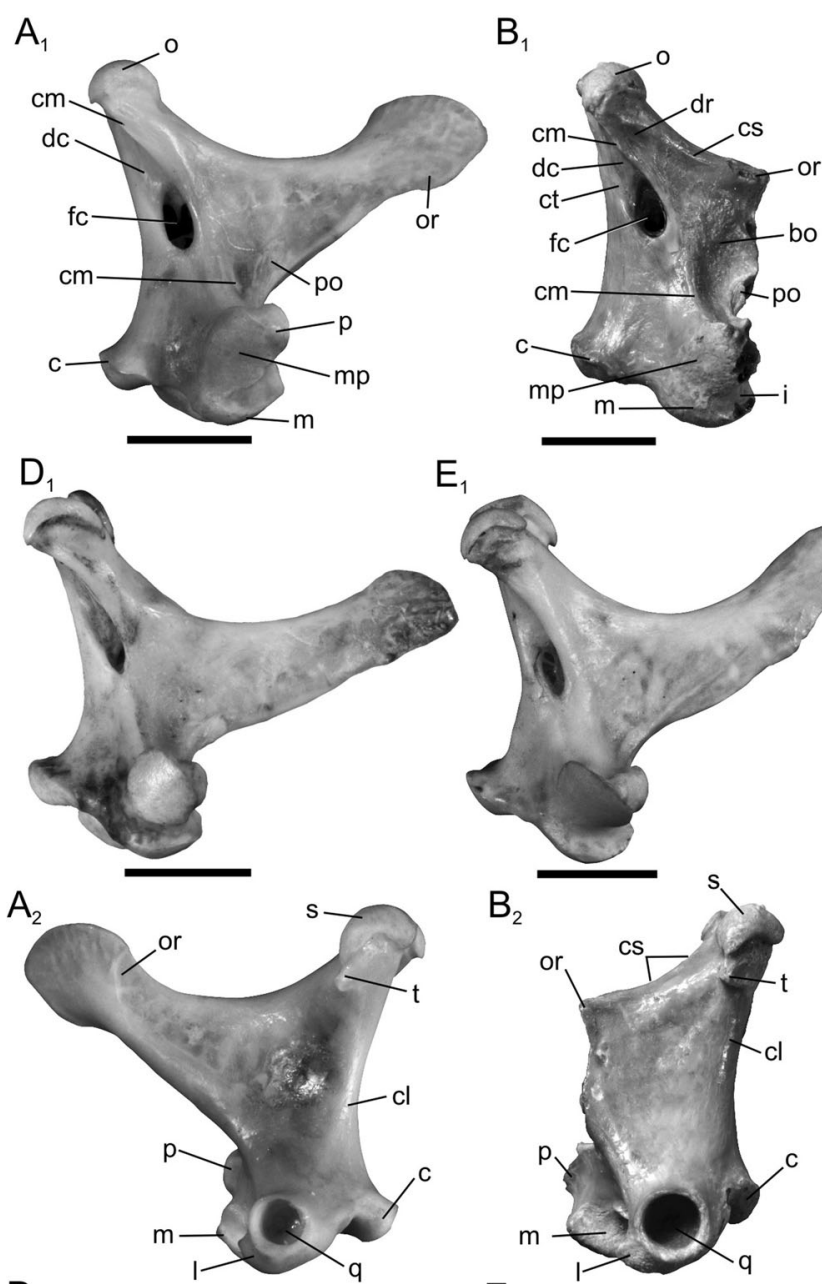

$D_{2}$

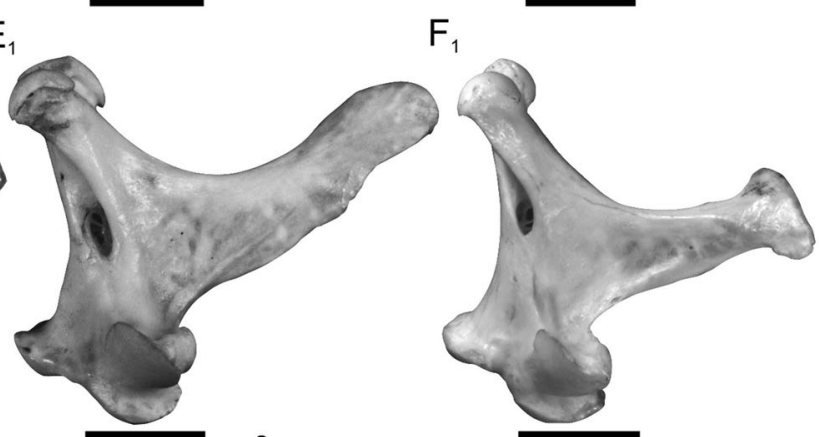

$\mathrm{B}_{2}$
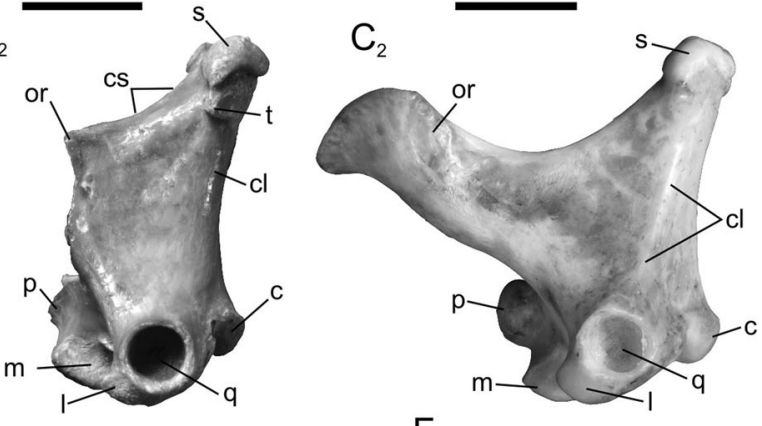

$\mathrm{E}_{2}$

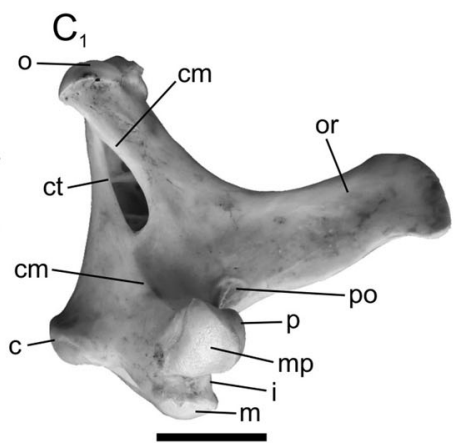

$\mathrm{F}_{2}$

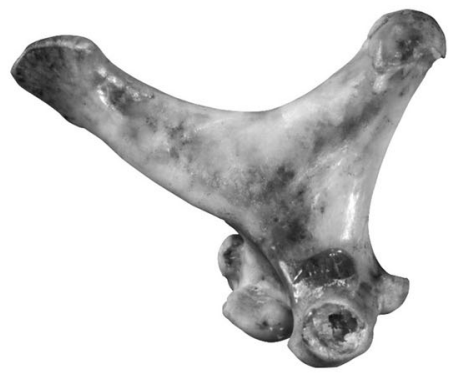

Scopus, Balaeniceps, and Pelecanus (a formally unnamed clade to which the name Pelecanoidea will be applied) have a rostromedial foramen.

Because of largely unsettled relationships within the Ardeidae, we use only two subfamily names, as defined by Martinez and Motis (1992): Ardeinae for the day herons and Botaurinae for the bitterns (Botaurus, Ixobrychus).

Institutional abbreviations: IPEE, A. N. Severtsov Institute of Ecology and Evolution (Laboratory of Biocenology and Historical Ecology), Russian Academy of Sciences, Moscow; ISEA, Institute of Animal Systematics and Evolution, Polish Academy of Sciences, NHM, Natural
History Museum, Tring; PIN, Borissiak Paleontological Institute, Russian Academy of Sciences, Moscow.

\section{Systematic palaeontology}

Family Ardeidae Vigors 1825

Diagnosis (for the quadrate): a single major pneumatic opening, foramen caudomediale. An additional medial mandibular facet on the pterygoid condyle. Caudal condyle offset far dorsally relative to the lateral condyle. In contrast 
to the Threskiornithidae, Pelecanoidea, and Suliformes, caudal condyle equally well separated from both the medial and lateral condyles; and mandibular facet of the lateral condyle strongly convex, and thus projecting distinctly beyond the ventral rim of the quadratojugal cotyla. The quadratojugal cotyla is with a deep fovea and a regular circular rim.

\section{Genus Nyctisoma nov.}

Type species: Nyctisoma robusta nov.

Etymology: a combination of word roots from the names Nycticorax and Tigrisoma, in reference to the combination of characters displayed by the fossil quadrate.

Diagnosis: quadrate with medial supraorbital crest bounding a distinct rostromedial depression. Medial supraorbital crest prominent, but wide and flattened (in contrast to cf. Pikaihao). Intercapitular vallecula with a prominent rugosity in the deep medial embayment of squamosal capitulum. Mandibular facets on the pterygoid and medial mandibular condyles confluent or at least contiguous caudally. The lateral mandibular condyle with a distinct medial labrum. Capitula end at approximately the same level (parallel to the line connecting the tips of mandibular condyles). Rostral tongue of the otic facet broad and rounded, longer than in Botaurinae, but shorter than in Nycticorax and Nyctanassa. Tuberculum subcapitulare angular, with the tip directed ventrolaterally.

Remarks: the quadrates are known for two out of five species representing extinct genera of Miocene ardeids. One of them, Matuku otagoense, does not cluster with any extant ardeid lineage (Scofield et al. 2010) and shows a correspondingly unique morphology of the quadrate. The quadrate of the other, identified as cf. Pikaihao (Mayr 2014), shows identical proportions and other similarities with Nyctisoma, but differs in at least four details that separate ardeid genera (see below): much shorter rostral slope of the otic capitulum and narrower medial condyle (as in the botaurines), lateral condyle without the medial labrum (as in Nycticorax and Nyctanassa), and the caudal mandibular condyle in a horizontal (perfectly transverse) orientation (as in Matuku), rather than being raised laterally whereby the caudal condyle comes closer the lateral condyle.

The remaining three Miocene ardeids have been described on postcranial elements, and thus cannot be directly compared with Nyctisoma, but none of them is likely to be congeneric. Ardeagrandis arborea and Zeltornis ginsburgi were very large, much larger than Nyctisoma. The tarsometatarsus of Ardeagrandis shows a unique morphology (Kurochkin and Ganya 1972 and pers. obs. by NVZ) without any potentially derived similarities to Nycticorax, Botaurinae or Tigrisoma. The coracoid of Zeltornis, which is said to combine similarities to Cochlearius and Nycticorax (Balouet 1981), clearly differs from the coracoid of Pikaihao bartleti (Worthy et al. 2013), and thus certainly from the unknown coracoid of cf. Pikaihao, which is closest to Nyctisoma. Proardeola walkeri was small, the size of Ardeola ralloides (Harrison 1979), and thus smaller than Nyctisoma. Unfortunately no comparisons to extant taxa have ever been drawn for this fossil. However, the new quadrate is very unlikely to represent the genus Proardeola, because big body size differences tend to be reflected in morphology and the genera of Ardeidae comprise either small-sized or medium-to-large-sized species; that is, no extant genus comprises both small-sized and medium-to-large-sized-species. In addition, Proardeola is known from the early Miocene of Europe, and the late middle Miocene bird fauna of Mongolia shares taxa with the middle and late Miocene rather than early Miocene faunas of Europe (Zelenkov and Kurochkin 2011; Zelenkov 2013). The new quadrate combines detailed similarities to, as well as generic-level differences from, cf. Pikaihao, suggesting a related genus. We conclude that Nyctisoma is unlikely to represent an existing genus and a low chance that remains is outweighed by the advantages of naming a well diagnosable and potentially significant fossil.

\section{Nyctisoma robusta nov.}

Etymology: the specific epithet refers to the robustness of the bone, especially as conveyed by the bulky medial supraorbital crest.

Holotype: left quadrate PIN 4869/52.

Type locality and horizon: Sharga, Shargyn-Gobi, Western Mongolia; Öoshin formation, late Middle Miocene (MN7-8, MNU 7).

Diagnosis: as for the genus.

\section{Description and comparisons}

In overall proportions, the quadrate is best compared to the botaurines (Fig. 1) and cf. Pikaihao (Mayr 2014; Fig. 2): it is more waisted (and slender) than in Tigrisoma lineatum, but less than in the night herons. The capitula end is at the same level (parallel to the line connecting mandibular condyles) as in Nycticorax, Botaurus stellaris, Ixobrychus eurythmus, Bubulcus ibis and Egretta alba. In Tigrisoma lineatum, Ixobrychus minutus, Ardeola ralloides, Butorides striata, Syrigma sibilatrix, Egretta garzetta, E. thula. E novaehollandiae, Ardea cinerea and Ardea purpurea, the otic capitulum projects much beyond the squamosal one. An intermediate condition was found in Tigrisoma mexicanum, Nyctanassa violacea, other Ardea species (A. herodias, A. goliath, A. melanocephala) and Egretta caerulea, where the otic capitulum projects only slightly 
beyond the squamosal one. Because of such intrageneric variation and poor definability, this character carries very little, if any, phylogenetic information. However, in the peculiar quadrates of $C$. cochlearius and Matuku otagoense (Scofield et al. 2010; Fig. 2), it is the squamosal capitulum that projects beyond the otic one, which is unusual among the Ardeidae, and thus may prove informative in terms of phylogeny and/or function.

The intercapitular vallecula is partly (rostrally) occupied by an irregular attachment rugosity that fills in a deep embayment of the medial margin of the squamosal capitulum and makes its medial slope convex (Figs. 1b, 3b1), as in cf. Pikaihao (Mayr 2014; Fig. 2b, e). The rugosity is more prominent than in any extant ardeid, but otherwise well comparable in shape and extent to that in Tigrisoma, and to a lesser degree, in Gorsachius and Botaurinae, whereas Nycticorax and Nyctanassa have the squamosal capitulum less excavated medially and the rugosity, if present, is smaller and (in Nycticorax) situated more centrally in the intercapitular vallecula.

The articular facet of the otic capitulum has a rostral tongue-shaped extension that is directed ventrolaterally,

Fig. 3 Left quadrates of Ardeidae. a Nycticorax nycticorax, b Nyctisoma robusta holotype PIN 4869/52 from the middle Miocene of Sharga locality (Western Mongolia), c Tigrisoma mexicanum, d Nyctanassa violacea, e Botaurus stellaris, f Gorsachius melanolophus in 1 , dorsal and 2, ventral views. Scale bars $5 \mathrm{~mm}$. Abbreviations as in Fig. 1. Asterisks mark the confluence of the primary mandibular facet on the medial condyle with the secondary mandibular facet on the pterygoid condyle
$\mathrm{A}_{1}$

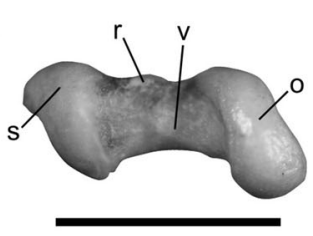

$D_{1}$

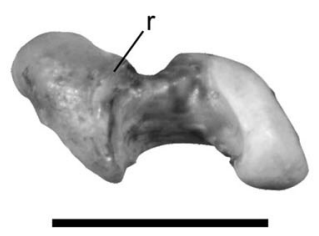

$\mathrm{A}_{2}$

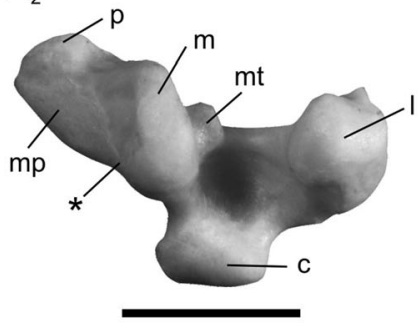

$\mathrm{D}_{2}$

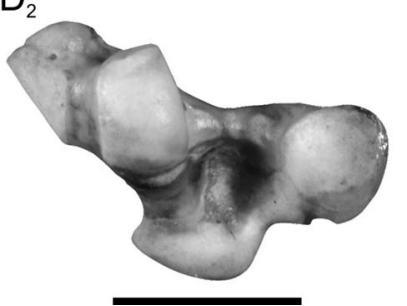

slightly narrower than the main dorsal part, and broadly rounded at the end. In its extent, the rostral tongue of the fossil is intermediate between a long tongue in Nycticorax and Nyctanassa (Fig. 1) and a short, only slightly descending tongue in the Botaurinae and cf. Pikaihao. It is best comparable to the extension in Gorsachius melanolophus and Tigrisoma mexicanum, whereas in Tigrisoma lineatum, the tongue is much longer, as in the night herons. High variability of the rostral tongue, which makes this feature unreliable for phylogenetic purposes, is best manifested in Ardea; the tongue is pointed and oblique in A. cinerea, more rounded and directed straight rostrally in A. herodias, and nearly absent in A. goliath.

Just ventral to the squamosal capitulum, there is a small subcapitular tubercle, angular in profile with the angle pointing ventrolaterally (Fig. 1b). The tubercle in Tigrisoma shows a similar geometry, with the angle pointing laterally, whereas in Nycticorax, Nyctanassa, Gorsachius and Botaurinae, the tubercles tend to point ventrally (especially in Nyctanassa) or remain rounded (Fig. 1).

Among other ardeids, the subcapitular tubercle was found to be more or less pointed in Cochlearius, Bubulcus
$\mathrm{B}_{1}$

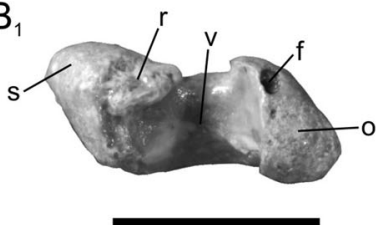

$\mathrm{E}_{1}$

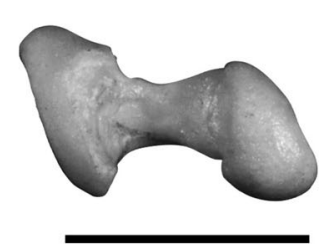

$\mathrm{B}_{2}$

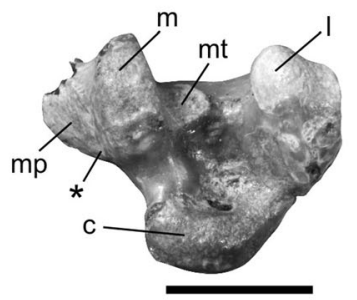

$\mathrm{E}_{2}$

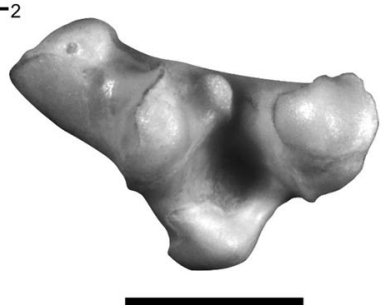

$\mathrm{C}_{1}$

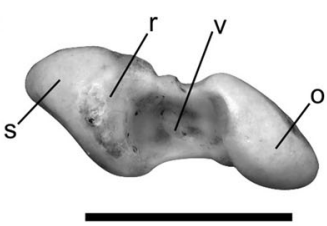

$F_{1}$

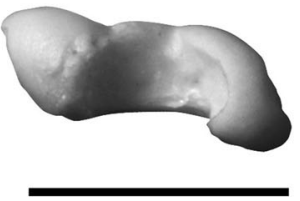

$\mathrm{C}_{2}$

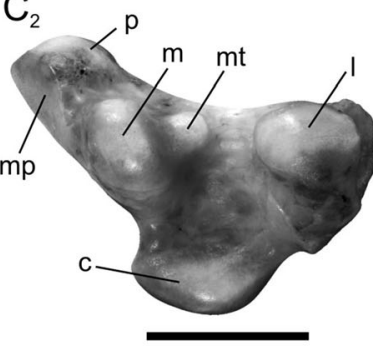

$\mathrm{F}_{2}$

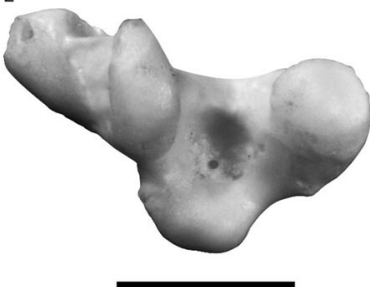


ibis and Egretta novaehollandiae, while in Ardea, Egretta (E. caerulea, E. alba, E. thula), Butorides striata and Ardeola ralloides, the tubercle is rounded, lobe-shaped or ear-shaped, sometimes reduced to a ridge (E. thula). Variation of this structure is hard to capture, and thus of little importance for phylogenetic purposes.

A bulky, prominent, but rounded medial supraorbital crest begins below the otic capitulum and narrows down to the dorsal margin of the orbital process (Fig. 1b1). Enclosed between the medial supraorbital crest and the medial crest is a distinct rostromedial depression (Fig. 2b1). A similar morphology appears to be present in cf. Pikaihao (Mayr 2014; Fig. 2c, e), except that the medial supraorbital crest is much thinner. Among the extant species, we found a weak medial supraorbital crest only in Ardea herodias. Besides, two barely marked ridges were found in a corresponding position in Ardea melanocephala, and a low bulge that may represent this crest was found in one (ISEA A74122/11) but not another specimen of Botaurus stellaris. Absent in Nyctisoma is the lateral supraorbital crest, which was found in Ardeola ralloides, Bubulcus ibis (as a diffuse bulge), Butorides striata, and, incomplete, in Ixobrychus minutus, Egretta thula, and Egretta caerulea.

The medial crest is reverse S-shaped as in Nycticorax nycticorax and cf. Pikaihao, but less so than in Tigrisoma (Fig. 2). The crest extends up to the pterygoid condyle and completely defines the basiorbital fossa as in Nycticorax, Nyctanassa, cf. Pikaihao, and Tigrisoma, whereas the botaurine crest tends to fade away ventrally. In Ardea, the medial crest extends to the pterygoid condyle and yet the fossa is almost nonexistent. The medial crest provides the rostral margin of the caudomedial foramen, which is large and pronouncedly guttate, that is, acute-angled dorsally and rounded ventrally, as in Nycticorax nycticorax. However, this foramen strongly varies even within a genus, being much narrower and less asymmetric in Nycticorax caledonicus. It is guttate in Ardea goliath, but subsymmetric and slit-like in Ardea cinerea and intermediate in $A$. herodias. It is guttate in Botaurus stellaris, while Ixobrychus minutus shows the inverted geometry. This character may possibly be species-specific, but seems of little significance for intergeneric relationships. The foramen is comparable in size with that of Nycticorax, Nyctanassa, and Botaurinae, but seems to be smaller than in Tigrisoma. Overall, in medial view, the fossil quadrate is most similar to that of Nycticorax nycticorax (Fig. 2). In caudal view, the dorsocaudal depression is poorly defined (essentially lacking) and the tympanic crest is not marked beyond the margin of the caudomedial foramen (Fig. 1b2). The tympanic crest is short and joins the medial crest at mid-height of the bone. The depression is shallow and the crest is short in Tigrisoma (Fig. 1c2), which shows the condition closest to that found in the fossil.
As in Tigrisoma and Gorsachius, there is no distinct orbitocotylar crest, which is represented by a diffuse bulge in Nycticorax and the bitterns, but is prominent in $\mathrm{Nyc}$ tanassa and Ardea. The orbitopterygoid crest is prominent (Fig. 1b1), with the edge flat to slightly concave rather than sharp. The orbitopterygoid crest provides attachment for short ligamentous strings connecting the quadrate to the pterygoid in the birds (such as the Ardeidae) that have a separate pterygoid articulation on the orbital process. The orbitopterygoid crest is present in the majority of Ardeidae, although it may be very low or absent in some Nycticorax and botaurine specimens (in Ixobrychus minutus, a groove instead of a crest was found). The pterygoid facet on the orbital process is preserved only in part.

The pterygoid condyle is damaged, with the pterygoid facet broken off. The secondary medial mandibular facet on the pterygoid condyle is caudally confluent with the primary facet on the medial condyle (Figs. 2b1, 3b2), and thus closes the intercondylar incisure (which remains open rostrally). These two medial mandibular facets are separated (disjunct) in all surveyed ardeids except for Nycticorax (Figs. 2a1, 3a2), and as far as one can tell from the photographs, in cf. Pikaihao (Mayr 2014; Fig. 2c). In Nyctanassa and at least some Ardea species, they are separated by a groove that is an extension of the intercondylar incisure. In Ardea cinerea (but not A. herodias and A. golitah) and Ixobrychus minutus (but not in Botaurus stellaris), the incisure was found to be filled by bone, and thus barely or not at all marked but the articular facets are separated.

In the medial condyle, the lateral trochlea is well-developed as in the other ardeids except for Nyctanassa (Figs. 1d, 3d2). The lateral condyle has the articular facet surrounded by a condylar labrum that projects both rostrally and medially as in the bitterns but not in Nycticorax, Nyctanassa (Fig. 1), or cf. Pikaihao (Mayr 2014; Fig. 2b, e). The medial projection of the labrum is moderate as in Botaurinae and Gorsachius, and not as strong as in Tigrisoma. However, the rostral profile and width of the intercondylar vallecula between the medial condyle and the trochlea of the lateral condyle are strikingly similar in Nyctisoma and Tigrisoma: the vallecula is wider than in the Botaurinae but narrower than in Gorsachius (Fig. 1). The caudal condyle is as in Nyctanassa and Trigrisoma; that is, transversely more elongate (and thus more pronouncedly labroid) than in Nycticorax and bitterns, and its dorsal margin is subliminally concave in caudal view (Fig. 1b2).

\section{Discussion}

The only consensus about the relationships within the family Ardeidae is that the bitterns Botaurinae and the day 
herons Ardeinae are monophyletic. Other than that, the relationships of the ardeid genera are largely unsettled. In particular, the relative placement of the Botaurinae and many genera (Cochlearius, Nyctanassa, Nycticorax, Syrigma, Tigrisoma) remain variable. Such ambiguities make it rather difficult to determine character polarities, except for those defined by the outgroups.

Tigrisoma has been recovered as the most basal ardeid lineage using mitochondrial sequences (Sheldon et al. 2000), confirming Bock's (1956) conclusion from a precladistic analysis of broad morphological data. Livezey and Zusi (2007) retrieved Tigrisoma as a sister group to the bitterns, which is close to the ancestry of crown-group ardeids. However, in two recent osteology-based phylogenies by McCracken and Sheldon (1998), who used evidence from Payne and Risley (1976), and by Worthy et al. (2013), Tigrisoma has been nested high up within the Ardeinae.

Nycticorax and Nyctanassa have been recovered together as a sister group to the Ardeinae using mixed morphological data (Livezey and Zusi 2007), with the bitterns being basal to both, as recovered from molecular sequence data (Sheldon et al. 2000). In contrast, the two osteology-based phylogenies (McCracken and Sheldon 1998; Worthy et al. 2013) recovered Cochlearius and night herons in the most basal position, which is in agreement with the oldest fossil ardeid showing Nycticorax morphology (Rasmussen et al. 1983), even if the Cochlearius lineage were even older. Whether recovered as the most basal or branching off closer to the herons, the night herons seem to be paraphyletic (McCracken and Sheldon 1998; Sheldon et al. 2000; Worthy et al. 2013), the molecular support for their monophyly being weak (Sheldon et al. 2000). This is relevant to the relationships of Nyctisoma quadrate, inasmuch it shows more similarities to Nycticorax than to Nyctanassa. As in other parts of the skeleton (Payne and Risley 1976; Kurochkin 1985), the quadrates of Nyctanassa and Nycticorax differ very substantially and the differences are much greater than between the Nycticorax species. Nyctanassa differs from Nycticorax in having the two medial mandibular facets separated (by the caudal extension of intercondylar incisure, as in other ardeids), a small (almost vestigial) trochlea of the medial condyle (clearly an autapomorphy even though in one specimen of Nycticorax nycticorax the trochlea was found barely developed), and the caudal condyle more extended transversely. Nyctisoma shares with Nycticorax all opposite character states, and with Nycticorax nycticorax a detailed similarity of the medial aspect.

The Nyctisoma quadrate combines the similarities to cf. Pikaihao, Nycticorax, and Tigrisoma. The confluence of the mandibular facets (on the medial and pterygoid condyles) in Nyctisoma, Pikaihao and Nycticorax is definitely plesiomorphic, as it is shared with nearly all other waterbirds (except for the Ciconiidae) including the immediate outgroup (Threskiornithidae), but absent in any other extant Ardeidae. In conjunction with the similarities to $\mathrm{Ti}$ grisoma, this suggests that the Nyctisoma lineage branched off prior to the separation of the Nycticorax and Tigrisoma lineages. This raises a possibility of Nyctisoma representing a stem-group ardeid. The question of whether Nyctisoma is a stem or crown-group ardeid largely depends on the relationships of Cochlearius, which was recovered as the most basal lineage in two recent osteology-based topologies (McCracken and Sheldon 1998, Worthy et al. 2013), but not in a classic morphological and molecular phylogeny (Bock 1955; Sheldon et al. 2000). Whether a stem-group or not, all evidence places Nyctisoma close to the ancestry of the crown group Ardeidae.

The best-defined similarities to the Tigrisoma quadrate, which in proportions is reminiscent of the day herons, are the location and shape of the vallecular rugosity (Fig. 3b1, c1) and caudal condyle (Fig. 1b2-c2). The phylogenetic status of the vallecular rugosity cannot be determined with certainty, but it may well be a plesiomorphic feature, as a corresponding extension of the squamosal capitulum is present in Scopus umbretta, whereas in the Threskiornithidae the vallecula is apomorphically obliterated, which obscures the ancestral condition. The plesiomorphic status of this feature is consistent with a basal placement of Tigrisoma (Bock 1956, Sheldon et al. 2000) and inconsistent with nesting this extant genus within the Ardeinae, as in the two recent osteology based phylogenies (McCracken and Sheldon 1998; Worthy et al. 2013).

The prime candidate for a synapomorphy is the presence of a distinct medial supraorbital crest that unites Nyctisoma and cf. Pikaihao. This crest is absent from the quadrates of nearly all other Ardeidae (except for one taxonomically isolated case in one species of Ardea) and the immediate outgroup (Threskiornithidae), but it may be present in Scopus (as the lateral margin of the rostromedial foramen) and the suliforms and frigate birds, where it is incomplete. The similarity of Nyctisoma and cf. Pikaihao is augmented by the identical proportions, the details of the capitula with the prominent vallecular rugosity, and the caudal condyle being a little prominent in a side view. However, the rugosity and a weak prominence of the caudal condyle are shared with Tigrisoma, and the orientation of the caudal condyle in caudal view is unique in cf. Pikaihao. The medial supraorbital crest remains as the primary evidence for a closer relationship of Nyctisoma and cf. Pikaihao.

The Nyctisoma quadrate is closest in size to that of Nycticorax nycticorax and Tigrisoma lineatum (Table 1). Because of the morphological similarities to both genera, Nyctisoma robusta probably had a similar body mass of $0.8-1.2 \mathrm{~kg}$ (Suppl. mat.), which is much less than in the 
Table 1 Measurements (in $\mathrm{mm}$ ) of the quadrate in Nyctisoma robusta and selected Ardeidae (in the order of decreasing height)

a The maximum width including the pterygoid condyle

b The complete measurement would exceed $11 \mathrm{~mm}$

\begin{tabular}{|c|c|c|c|c|}
\hline Species & Height & Capitular width & Ventral width ${ }^{\mathrm{a}}$ & Condylar width \\
\hline Ardea goliath ISAE A/3972/83 & 21.8 & 10.0 & 15.1 & 11.0 \\
\hline Ardea herodias ISAE A/4103/84 & 18.2 & 7.6 & 11.6 & 8.4 \\
\hline Nyctisoma robusta PIN 4869/52 & 17.1 & 6.8 & $10.3+^{\mathrm{b}}$ & 8.2 \\
\hline Nycticorax nycticorax $\widehat{\jmath}$ ISAE A/6343/06 & 17.0 & 6.6 & 11.1 & 7.4 \\
\hline Nycticorax nycticorax ô IPEE 1113 & 16.8 & 7.1 & 11.0 & 8.1 \\
\hline Tigrisoma lineatum PIN 22-3-1 & 16.8 & 7.2 & 11.4 & 8.4 \\
\hline Ardea cinerea IPEE 1072 & 16.5 & 5.9 & 10.2 & 8.0 \\
\hline Ardea cinerea IPEE 2635 & 16.3 & 5.7 & 10.8 & 7.9 \\
\hline Ardea cinerea IPEE 1678 & 16.3 & 5.9 & 10.5 & 7.7 \\
\hline Botaurus stellaris §ิ IPEE 1724 & 15.9 & 5.7 & 10.1 & 7.1 \\
\hline Nycticorax nycticorax IPEE 873 & 15.8 & 6.4 & 10.5 & 7.4 \\
\hline Botaurus stellaris IPEE 2472 & 15.6 & 5.6 & 9.9 & 7.0 \\
\hline Botaurus stellaris 今̊ IPEE 1648 & 15.5 & 5.4 & 9.9 & 6.6 \\
\hline Botaurus stellaris + IPEE 2507 & 15.4 & 5.4 & 9.7 & 6.6 \\
\hline Nycticorax nycticorax $q$ ISAE A/3496/78 & 15.4 & 6.3 & 10.3 & 6.8 \\
\hline Botaurus stellaris + ISAE A/6342/06 & 15.2 & 5.2 & 10.0 & 7.2 \\
\hline Nyctanassa violacea PIN 21-1-1 & 14.8 & 5.4 & 9.7 & 7.3 \\
\hline Botaurus stellaris IPEE 1029 & 14.5 & 5.2 & 8.6 & 6.0 \\
\hline Ardea alba IPEE1931 & 14.2 & 5.2 & 8.2 & 6.5 \\
\hline Ardea alba IPEE1249 & 14.1 & 5.0 & 8.4 & 6.4 \\
\hline Botaurus stellaris + PIN 23-12-2 & 13.7 & 5.0 & 8.5 & 6.2 \\
\hline Botaurus stellaris ISAE A/7422/11 & 13.7 & 5.3 & 8.6 & 6.2 \\
\hline Ardea purpurea $\widehat{\jmath}$ IPEE 2493 & 13.6 & 4.8 & 8.4 & 6.1 \\
\hline
\end{tabular}

and large-headed forms (Suppl. mat.), which may explain why all the Ardeidae, large and small, fly with the head withdrawn between the shoulders as opposed to other long-necked birds, such as anhingas that also use a darting stroke in catching prey. This also raises the question about the primary function(s) of the neck kink in the evolution of herons. While it obviously facilitates the darting stroke at feeding (Kral 1965), we propose that it evolved in response to the increase of head size, to keep the heavy head closer to the center of gravity in flight. Aside from the Ardeidae, the head is kept more or less retracted in flight by large-headed waterbirds (in the present, phylogenetic meaning of this term), including the shoebills, pelicans, hammerkops and, characteristically, the marabou (Leptoptilos), but not other storks. We therefore propose that the head retraction in the large Ardeinae with relatively small heads (Suppl. mat.) evolved from smaller, large-headed ardeids and has been maintained as an adaptation for the darting stroke that is more advanced in the Ardeinae than in Nycticorax (Kral 1965). The proposed heavy-head-first hypothesis is consistent with the basal position of Cochlearius cochlearius (McCracken and Sheldon 1998; Worthy et al. 2013), which shows little or no specialization for the darting stroke and has a head that is heavier than other herons of comparable size (Suppl. mat.). 
Acknowledgments This work has been supported by Poland's National Science Center (NCN) grant 2013/11/B/NZ8/04376 to A. E., Russian Foundation for Basic Research grant 14-04-01123 and President's of Russian Federation grant MK-7463.2013.4, both to NVZ. We are very thankful to Z. Bocheński (Instytut Systematyki i Ewolucji Zwierzạt PAN, Krakow), G. Mayr (Forschungsinstitut Senckenberg, Frankfurt/M), A. B. Savinetsky (IPEE, Moscow), and J. White and R. Prys-Jones (Natural History Museum, Tring) for access to osteological specimens, and again to G. Mayr for showing the orginal photographs of the cf. Pikaihao quadrate. Also, our manuscript has greatly benefitted from G. Mayr's constructive review.

Open Access This article is distributed under the terms of the Creative Commons Attribution License which permits any use, distribution, and reproduction in any medium, provided the original author(s) and the source are credited.

\section{References}

Adams CT (1955) Comparative osteology of the night herons. Condor 57:55-60

Balouet JC (1981) Zeltornis ginsburgi n. g., n. sp. (Ardeidae, Aves), Héron géant du Miocène inférieur du Djebel Zelten (Libye). CR Acad Sci Paris 93:235-239

Bas C (1954) On the relation between the masticatory muscles and the surface of the skull in Ardea cinerea (L.). Koninkl Nederl Akademie Wetenschappen C 57:678-685

Becker JJ (1986) An early heron (Aves, Ardeidae, Ardea) from the middle Miocene of Nebraska. J Paleontol 60:968-970

Bock WJ (1956) A generic review of the family Ardeidae (Aves). Amer Mus Novitates 1779:1-49

Elzanowski A, Paul GS, Stidham TA (2000) An avian quadrate form the Late Cretaceous Lance Formation of Wyoming. J Vertebr Paleontol 20:712-719

Hackett SJ, Kimball RT, Reddy S, Bowie RCK, Braun EL, Braun MJ, Chojnowski JL, Cox AW, Han K, Harshman J, Huddleston CJ, Marks BD, Miglia KJ, Moore WS, Sheldon FH, Steadman DW, Witt CC, Yuri T (2008) A phylogenomic study of birds reveals their evolutionary history. Science 320:1763-1768

Harrison CJO (1979) The herons (Ardeidae) of the Old World Tertiary. Tertiary Res Spec Pap 5:11-17

Kral B (1965) Functional adaptations of Ciconiiformes to the darting stroke. Acta Soc Zool Bohemoslov 29:377-391

Kurochkin EN (1985) Birds of the Central Asia in Pliocene. Trans Joint Sov-Mongol Paleontol Exped 26:1-120
Kurochkin EN, Ganya IM (1972) Ptitsy srednego sarmata Moldavii (Birds from the middle Sarmatian of Moldova). In: Pozvonochnye neogena i pleistotsena Moldavii (Vertebrates of the Neogene and Pleistocene of Moldova). Ştiinţa (Shtiintsa), Chişinău (Kishinev): 45-70

Kushlan JA, Hancock JA (2005) Herons. Oxford University Press, Oxford

Livezey BC, Zusi RL (2007) Higher order phylogeny of modern birds (Theropoda, Aves: Neornithes) based on comparative anatomy: 2. analysis and discussion. Zool J Linn Soc 14:1-95

Martinez A, Motis A (1992) Family Ardeidae (herons). In: del Hoyo J, Elliott A, Sargatal J (eds) Handbook of the birds of the world, vol 1. Lynx Edicions, Barcelona, pp 376-429

Mayr G (2009) Palaeogene fossil birds. Springer, Berlin-Heidelberg

Mayr G (2014) On the middle Miocene avifauna of Maboko Island, Kenya. Geobios 47:133-146

McCracken KG, Sheldon FH (1998) Molecular and osteological heron phylogenies: sources of incongruence. Auk 115:127-141

Mustoe GE (1993) Eocene bird tracks from the Chuckanut formation, northwest Washington. Can J Earth Sci 30:1205-1208

Payne RB, Risley CJ (1976) Systematics and evolutionary relationships among the herons (Ardeidae). Mus Zool Univ Michigan Misc Publ 150:1-115

Rasmussen DT, Olson SL, Simons EL (1987) Fossil birds from Oligocene Jebel Qatrani Formation, Fayum Province, Egypt. Smithson Contrib Paleobiol 62:1-20

Scofield RP, Worthy TH, Tennyson AJD (2010) A heron (Aves: Ardeidae) from the early Miocene St Bathans Fauna of southern New Zealand. Rec Austral Mus 62:89-104

Sheldon FH, Jones CE, McCracken KG (2000) Relative patterns and rates of evolution in heron nuclear and mitochondrial DNA. Mol Biol Evol 17:437-450

Worthy TH, Worthy JP, Tennyson AJD, Scofield RP (2013) A bittern (Aves: Ardeidae) from the early Miocene of New Zealand. Paleontol J 47:1331-1343

Zelenkov NV (2011) Ardea sytchevskayae sp. nov., a new heron species (Aves: Ardeidae) from the middle Miocene of Mongolia. Paleontol J 45:572-579

Zelenkov NV (2013) Cenozoic phoenicopteriform birds from Central Asia. Paleontol. J 47:1323-1330

Zelenkov NV, Kurochkin EN (2011) Sovremennoe sostoyanie izuchennosti ptitz neogena Tsentralnoi Asii (The current state of knowledge of Neogene birds of Central Asia. In: Martynovich NV (ed) A. Ya. Tugarinovu posvyashaetsya... Sbornik nauchnykh statei (Dedicated to A. Ya. Tugarinov... A collection of scientific papers). Krasnoyarskii Kraevoi Kraevedcheskii Musei, Krasnoyarsk, pp 44-70 